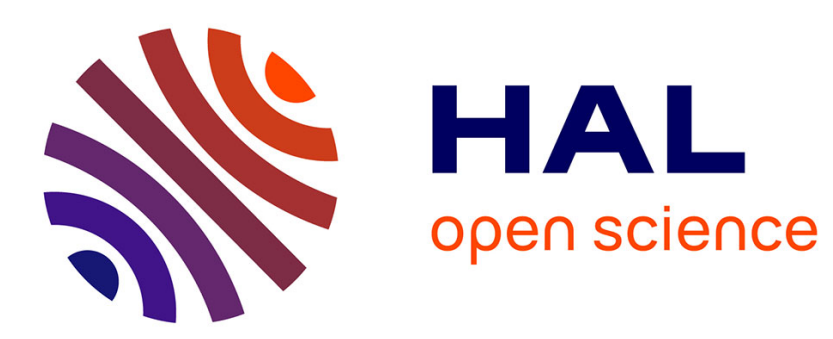

\title{
The tongnian network in Matteo Ricci's intellectual network
}

Frédéric Wang

\section{To cite this version:}

Frédéric Wang. The tongnian network in Matteo Ricci's intellectual network. Filippo Mignini. New Perspectives in Studies on Matteo Ricci, Quodlibert, p. 59-75., 2019, 978-88-2290-254-2. hal02021120

\section{HAL Id: hal-02021120 \\ https://hal.science/hal-02021120}

Submitted on 19 Oct 2019

HAL is a multi-disciplinary open access archive for the deposit and dissemination of scientific research documents, whether they are published or not. The documents may come from teaching and research institutions in France or abroad, or from public or private research centers.
L'archive ouverte pluridisciplinaire HAL, est destinée au dépôt et à la diffusion de documents scientifiques de niveau recherche, publiés ou non, émanant des établissements d'enseignement et de recherche français ou étrangers, des laboratoires publics ou privés. 
The tongnian network in Matteo Ricci's intellectual network ${ }^{1}$

\author{
Frédéric Wang
}

\title{
Introduction
}

Tongnian 同年 literally means “same year” or “same age”. But in its normal usage it refers to the candidates who successfully passed the examination the same year, regardless of their age. As a social phenomenon, it was generated by the system of civil examinations ( $k e j u$ 科擧) of imperial China. "The social and cultural effects of forming alliances between graduates of a particular examination who differed widely in age meant that neither the young nor the old could seek solidarity in their own age group. A t'ung-nien (same year of graduation) reunion would be far different from a college reunion in the West." ${ }^{2}$ Furthermore, the tongnian usually entered the officialdom the same year and became close colleagues at one point or another in their official carriers. Their relationship is complicated. Even though it can also be a source of rivalry or conflicts, the word tongnian is first and foremost a synonym for friendship or brotherhood. ${ }^{3}$ The master-disciple (shisheng 師生) relationship is related to the

I This paper develops my previous research presented in my article "Matteo Ricci et les lettrés de Nankin," in I. Landry-Deron (ed.), La Chine des Ming et de Mattéo Ricci (Paris: Cerf, 2013), pp. 29-42 and its revised Chinese version: "Li Madou yu I 589 nian de jinshi," (利瑪寶與 1589 年的進士; Matteo Ricci and the jinshi of I 589 ) in Guoji rulian (國 際儒聯), ed., Ruxue: Shijie heping yu fazhan. Jinian Kongzi danchen 2565 zhounian guoji xueshu buiyi lunwenji (儒學: 世界和平與發展. 紀念孔子誕辰 2565 周年國際學術會議論文 集) (Beijing: Jiuzhou chubanshe, 20I5), vol. 3, pp. 216-24. This research was made possible by the indexes in both the Della entrata della Compagnia di Giesù e Christianità nella Cina (Mecerata: Quodilbert, 2000) and the Lettere (Macerata: Quodlibet, 200I). I would like to express my warmest thanks to Marie Laureillard and Alexandre Shiele for having reviewed my paper.

${ }^{2}$ B. Elaman, A Cultural History of Civil Examinations in Late Imperial China (Berkeley; Los Angeles: University of California Press, 2000), p. 26I.

${ }^{3}$ For the tongnian networks in the Song dynasty, see Qi Chenyun (祁琛雲), Bei Song kejia tongnian guanxi yu shidaifu pengdang zhengzhi (北宋科甲同年關係與士大夫朋黨政 治; The Tongnian Relationship in Civil Examinations and the Politics of the Partisan Fractions in the Northern Song) (Chengdu: Sichuan daxue chubanshe, 2013). 
tongnian, especially since the middle of the Tang Dynasty, when laureates of the civil examinations began to consider the Chief Examiner their master (zuozhu 座主). So they called themselves his disciples (mensheng 門 生). ${ }^{4}$ Sometime an examiner might even compare a laureate to land property (zhuangtian 莊田). Chen Yinke 陳寅恪 (I890-1969) said: “When an examiner considers a disciple as a land property, his search of reward in distributing favours is obvious” (座主以門生為莊田, 則其施恩圖報之意 显然而知). 5 In spite of the prohibitions enacted by a number of emperors in all dynasties, this type of master-disciple relationship continued to dominate the relation between examiners and laureates in late imperial China. The social importance of the master-disciple relationship mirrors the moral qualities of each actor.

In order to avoid the re-emergence of political factions resulting from the strong links between examiners and laureates that affected the Tang Dynasty, a palace examination (dianshi 殿試) was created during the Song dynasty in 973 . This ultimate stage of civil examinations was chaired in theory by the Emperor himself. It followed the examination organized by the Ministry of Rites (shengshi 省試 or huishi 會試 in the Ming Dynasty). Therefore, the emperor himself theoretically became the mentor of all jinshi. However, the link between chief examiners of the shengshi and laureates continued to be very important and had a great influence on their official carrier or their life. In I057, it was decided that all successful candidates to the shengshi would be admitted to the dianshi, even though the ranking of the buishi and dianshi sometimes differed.

It is very difficult for us to imagine that Matteo Ricci was conscious of the importance of the tongnian network. It does not imply that he was insensitive to social relations. In his Journals, he frequently reports making friends. We can find that several of his friends were tongnian. In this article, I will focus my attention on a number of jinshi of 1565 and I 589 and their role in Ricci's network. My aim is not only to show the importance of the tongnian networks but also that of the master-disciple relation between Chinese literati in the context of Ricci's missionary history. Generally speaking, the research on tongnian networks during the Ming dynasty deserve more consideration.

${ }^{4}$ See Gu Yanwu, Rizhi lu 日知錄 (Record of Knowledge Gained Day by Day), juan I6-17, Siku edition, ia800208.us.archive.org/27/items/06061665.cn/0606I665.cn.pdf, Rizhi lu, juan 17-38; WU Zongguo (吴宗國), Tangdai keju zhidu (唐代科举制度; The System of Civil Examinations in the Tang Dynasty) (Shenyang: Liaoning daxue chubanshe, 1997), p. $2 \mathrm{IO}-2 \mathrm{I}$.

Chen Yinke (陳寅恪), Tangdai zhengzhishi shulun gao (唐代政治史述論稿; Draft Account of Tang Dynasty Political History) (Taipei: Shangwu yinshuguan, 1994), p. 92. 


\section{Wang Honghui}

One of the key intermediaries between Ricci's Chinese friends is no doubt Wang Honghui 王弘誨（I542-16I5）, zi Zhongming 忠銘. A native of the Island of Hainan in Guangdong province, he passed the examinations of his province as Dispatched Optimus (jieyuan 解元) in I 56I and became jinshi in I 565. With Qiu Jun 邱濬 (I42I-I495) and Hai Rui 海瑞 (I I I4-I 587), Wang Honghui is one of the three personalities of the Island of Hainan in the Ming dynasty. He was a tongnian and friend of Xu Guo 許國 (I 527-I 596) and Zhao Kehuai 趙可懷 (I 54I-I603).

Wang Honghui entered the Hanlin Academy as jinshi and was involved in the compilations of the Veritable Records (shilu 實錄) of the eras of Muzong and Shizong. He successively served as Director of the Nanjing Imperial School (Guozi jian 國子监), Vice-Minister of the Ministry of Personnel, Minister of Rites in Nanjing. Wang was a devoted admirer of his compatriot Hai Rui. When Hai Rui was arrested in I 566 for addressing to the Emperor Shizong his well-known Memorial on Peace and Order (Zhi'an shu 治安疏), which vehemently criticized the Emperor for his behavior and his search for immortality, the young jinshi Wang Honghui, as Assistant Compiler (shujishi 庶吉士) at the Hanlin Academy, visited him in prison. Wang Honghui wrote a biography of Hai Rui: Hai Zhongjie gong zhuan 海忠介公傳, ${ }^{6}$ after his death in I 587.7 This fact is significant, since many friends of Matteo Ricci wrote a biography of Hai Rui. The $X u$ Canshu 續藏書 (An Addendum to $A$ Book to Hide) of Li Zhi 李䞇 ( I 527-1602) includes the “Taizi shaobao Hai Zhongjie gong zhuan” 太子少保海忠介公傳 (Biography of Hai Rui, Junior Preceptor of the Crown Prince). Zou Yuanbiao 鄒元標 (I 55I-I624) wrote a preface to the Hai Zongjie gong wenji 海忠介公文集 (Collected Works of Hai Rui) published in I618 (I6th year of the reign of Wanli). Zou Yuanbiao emphasises Hai Rui's admiration for Lu Jiuyuan 陸九淵 (I I 39- I I 93), a wellknown thinker of the Southern Song. ${ }^{.}$Zou Yuanbiao was a scholar-official of the Jiangyou School 江右 (Jiangxi), a branch of Wang Yangming's 王陽明 (I472-I 529) Intuitionism. He was politically a partisan of the Donglin faction. Ricci will meet him in Beijing in the I60os. In short, Ricci was himself

${ }^{6}$ In Hai Rui (海瑞), Hai Rui ji (海瑞集; Works of Hai Rui) (Beijing: Zhonghua shuju, I962), pp. 530-33.

7 For a presentation of the friendship between Hai Rui and Wang Honghui, see Wang Liping (王力平), Haiyu mingchen: Wan Ming Wang Honghui yanjiu (海隅名臣——晚明王 弘誨研究; A Famous Minister from the Maritime Boundary: Research on Wang Honghui of the Late Ming) (Haikou: Hainan chubanshe, 2008), chapter 4, pp. 60-70. I am very indebted to this book.

${ }^{8}$ Rui 海瑞, (海瑞), Hai Rui ji (海瑞集; Works of Hai Rui), pp. 606-7. 
acquainted with literati of good repute and who appreciated the integrity of Hai Rui, for admonishing the Emperor at the risk of his own life.

Philosophically speaking, Wang Honghui was connected to the Taizhou School, founded by Wang Gen 王艮 (I483-I 54I), a disciple of Wang Yangming. In a number of texts included in his Tianchi cao 天池草 (Herbs from the Heavenly Pond), he emphasizes the heart-mind (xin 心) in Confucian learning. Nevertheless, Wang Honghui had a great openness of mind and had many good friends among Taoists and monks like Xuelang Hong'en 雪浪洪恩 (I545-1608), alias Sanhuai 三懷, with whom Ricci had a famous debate on philosophical and religious questions, and his colleague Hanshan Deqing 憼山德 清 (I 546-1623). Ricci mentioned these two Buddhist masters in his missionary accounts. In I 589, the Grand Academician (daxueshi 大學士) Xu Guo and the Vice-Minister of Personnel Wang Honghui were Chief Examiners of the huishi. They recruited Jiao Hong, Zhu Shilu 祝世祿 (I 539-16IO), Wang Kentang 王肯堂 (I 549-I6I3), Huang Hui 黄輝 (I559-I6I2) who became jinshi the same year. Thanks to Wang Honghui who permanently retired in I 599 , Ricci, whose first encounter with him goes back to I 592 in Shaozhou, Guangdong province, grew to know many high-ranking officials. Among others: Ye Xianggao 葉向 高 (I559-I627), Yang Daobin 楊道賓 (I552-I609), both Vice-Ministers of the Ministry of Personnel in Nanjing, Guo Zhengyue 郭正域 (I554-1612), Rector (jijiu 祭酒) of the Guozi jian 國子监 in Nanjing. These personalities will in time become Ministers in Beijing where they would continue to protect Ricci and his fellows. Wang Yinglin 王應麟 (I 545 -1 620), a former Vice Sub-prefect of Nanxiong 南雄, in Guangdong, where he met Ricci, and current Governor of Zhenjiang, had offered Zhao Kehuai 趙可懷 (I 54I-I603), Circuit Governor (xunfu 巡撫) of Yingtian 應天, a copy of Ricci's World map (Kunyu wanguo quantu 坤舆萬國全圖). Zhao Kehuai, who became a jinshi in I 564 , was a closer friend and a tongnian of Wang Honghui. Ricci spent the Spring Festival of I 599 at Zhao Kehuai's home. Wang Yingling was to become governor in Beijing and compose the epitaph of Ricci's tombstone in I6I5.

We know that I 595 was an important year for Ricci's mission in China, because after I 2 years in Guangdong province, he decided to go to Nanjing and Beijing. He and his companions shed their monk's robes and dressed as literati. They considered themselves taoren 道人 (man of the Tao), the equivalent of ximcai 秀才 (bachelor), before they set on to the Southern Capital. ${ }^{9}$ But war raged between Japan and Korea and any foreigner staying in either capitals became a suspect. One of his old friends,

9 J. Gernet, Jaques, "La politique de conversion de Matteo Ricci en Chine," Archives des sciences sociales des religions, 36 (1973), pp. 7 I-89, 75 . 
$\mathrm{Xu}$ Daren 徐大任, jinshi of I 568 and Vice-minister of the Ministry of Works in Nanjing, said to him: "Nankin [...] is no place for a foreigner to establish a home, because his very presence might be sufficient to cause an uprising. Moreover, as he informed the Father, he was making a great mistake in coming to see him, because the other Magistrates could take occasion from this to accuse him the crime of inviting a foreigner to Nankin. [...] so he sent Ricci away, alleging many reasons why he could not help him in any way, and advising him to leave Nankin as soon as possible and betake himself to other parts." ${ }^{\circ}$ Though Ricci was extremely disappointed at the reaction of $\mathrm{Xu}$ Daren, the suspicion toward foreigners in Beijing and Nanjing at that time should not be underestimated. Ricci's first stay in Nanjing lasted only is days before returning to the South of China. But, rather than going back to Guangdong, he stayed in Nanchang, where he was warmly welcomed by princes and literati alike. It was in Nanchang that Ricci composed his first Chinese text: Jiaoyou lun 交友論 (On friendship), dedicated to the prince of Jian'an. The text, mainly a compilation of stoic maxims on the question of friendship with references to Aristotle, Cicero, Plutarch, Augustine of Hippo, and others, established the literary reputation of Ricci. The book, based on Aristotelian ethics and in contrast to the idea of Christian fraternity, advocates that friendship is the preference for the company of Gentlemen. It will be widely disseminated among the Chinese literati, many of whom would have read the book before their first encounter with the author.

In I 598, Ricci departed once more for Nanjing. When Wang Honghui, who had promised to accompany him to Beijing for the correction of the calendar, learnt that Ricci and his colleagues would go to Nanjing with gifts prepared for the emperor:

In reply, the President [Wang Honghui] told them that he would be pleased, not only to have them accompany him to Nankin, but to Pekin also, and that he would have to go there in about a month to congratulate the King on his birthday. That would be on the seventeenth day of the eighth moon, or as we would say on the seventeenth of September. He thought that would be quite an opportune occasion on which to offer the King presents, such as he had never seen before..$^{\text {II }}$

Nevertheless, Nanjing remained closed to foreigners. Ricci and his colleagues were not allowed to stay. They rented a boat and lived in it for a short time. After visiting a number of personalities, especially, the

${ }^{10}$ China in the Sixteenth Century: The Journals of Matthew Ricci I583-I6IO, p. 27 I.

${ }^{11}$ Ibid, p. 298. 
"Viceroy" Zhao Kehuai, of whom Ricci praised the "vivacious spirit and excellent conduct", and told of the murder "by the King's relatives," they followed the Grand Canal to Beijing. They arrived at the end of September I 598. In Beijing, they faced the same obstacles as in Nanjing. Wang Honghui could do nothing for them and recommended them to return south. Ricci went back south and stayed a few days at Qu Taisu's 矍太素 [Qu Rukui 翟汝㪣, I 549-I6I I] home in Suzhou. Qu Taisu was his first disciple. Ricci went again to Nanjing on June 2, I 599. In contrast to his two previous experiences in Nanjing, the third one was a total success. "What pleased them most was that Father Matthew was being honoured by everyone and looked upon as a prodigy, in a city from which he was once chased away, and where, on another occasion, he had had to go into hiding." " ${ }^{3}$ This time, Ricci would stay there one year and three months. He met many literati and truly discovered the Second Capital. It would prove crucial for his next adventure in Beijing:

Without the relationships established in the Southern Capital, the experience accumulated in dealing with the officials, the idea of Western Confucians in the academic world, the reconnaissance from major scholars, the support of Portuguese traders who profited from his first success with the gentry society in Nanjing, the establishment of Ricci in Beijing would surely have been more difficult.

如果沒有在南都建立的人際關係，如果沒有在官場周旋的應對經驗，如果沒有 在學界樹起的西儒形像，如果沒有在士林結識的名流的揄揚，如果沒有對他在南京 官紳社會初獲成功而驚喜不已的澳門葡商倍力支援, 那麼利瑪竇要在北京立足, 必 定困難得多。 ${ }^{14}$

One detail should be underlined: when Ricci arrived for the last time in Nanjing, the Japanese-Korean War had come to an end with the death of the daimyo Toyotomi Hideyoshi 豊臣 秀吉 (I 537-I 598) in September I 598. Officials of the Southern Capital had no reason to prevent him from staying. Most of them followed the example of Wang Honghui whose role was essential for Ricci's stay in Nanjing until Wang Honghui’s definitive retirement. Numerous pages of the fourth book of Ricci's Journals are devoted to Wang Honghui and his hospitality toward the Jesuit father.

${ }^{12}$ Ibid, p. 302.

${ }^{13}$ Ibid., p. 345.

${ }^{14}$ Zhu Weizheng (朱維錚), ed., Li Madou zhongwen zhuyi ji (利瑪竇中文著譯集; Collection of Chinese Writings and Transla-tions by Matteo Ricci) (Shanghai: Fudan daxue chubanshe, 2007), p. 5 . 


\section{Wang Kentang}

According to the statistics of professor Lin Jinshui 林金水, Ricci made the acquaintance of $\mathrm{I}^{2} 2$ personalities in China. He met thirty-one of them in Nanjing during his short stay. ${ }^{15}$ Though this number does not include those he had met before his arrival in Nanjing and with whom he may have remained in contact with while in the second capital, it shows the importance of Nanjing's literati networks in Ricci's own network. Ricci was well aware that "all friends were not credible." ${ }^{\text {"6 }}$ Before he arrived in Nanjing, many literati had read his works or received his gifts. Now, I will focus on a number of his friends in Nanjing among those whose received their jinshi in 1589 .

The literature on Ricci's exchanges with Jiao Hong and his close friend Li Zhi is abundant. Jiao Hong chaired Beijing's xiangshi 鄉試 in I 597 , which Xu Guangqi 徐光啓 (I 562-I633) successfully passed. Xu Guangxi will convert to Catholicism and become Ricci's disciple. He will translate into Chinese, with Ricci's collaboration, the first six chapters of Euclid's Elements, from the Latin version (I 574) of Christophorus Clavius (Christoph Klau, I 538-16I2), Ricci's former German professor of mathematics and sciences at the Jesuit Collegio Romano. In short, both Jiao Hong and Ricci were masters of Xu Guangqi.

Li Zhi offered Ricci a poem in which he used Zhuangzi's metaphors to refer to Ricci's itinerary. The poem was written on a fan, which for Ricci's Western tradition played the same function as gloves. In a letter addressed to a friend in I600, Li Zhi wrote that Ricci could "speak and write Chinese, follow the Chinese rites” (言我此間之言，作此間之文字，行此間 之儀禮). But Li Zhi did not really understand the objective of Ricci’s pres-

is Lin Jinshui (林金水), Li Madou yu Zhonggno (利瑪寶與中國; Matteo Ricci and Chine) (Beijing: Zhongguo shehui kexue chubanshe, 1996), pp. 286-316. On the limits of the statistics of Lin, see N. Standaert (ed.), Handbook of Christianity in China: Volume One, 635-I800 (Leiden: Brill, 2000), p. 475, note 2.

${ }^{16}$ Élisabeth Rochat notes (free translation): "Conversions are rare and as soon as the missionary has left, few are the new converts who remain loyal; the question is: did they convert to Christ or to Ricci? All Chinese friends are not reliable, and even for the best among them, how deep is truly their understanding? The same is true of his fellow Westerners, some of whom criticize him" (Les conversions sont rares et sitôt que le missionnaire n'est plus là, bien peu des nouveaux convertis restent fidèles; à se demander s'ils sont convertis au Christ ou à Ricci. Les amis chinois sont loin d'être tous fiables et même avec les meilleurs d'entre eux, jusqu'où va [vont] vraiment l'entente et la compréhension? Jusqu'à ses congénères occidentaux dont certains le critiquent), "Preface" to V. Cronin, Matteo Ricci. Le sage venu de l'Occident, translation Jane Fillon, Albin Michel (Édition au format de poche, 2010), p. I3. 
ence in China: "But I do not know why he came here. Though I met him three times, I still do not know why he came here. I thought that he would transform the learning of the Duke of Zhou and Confucius with his own learning. But it would be too stupid. I am afraid it was not his intention" (但不知到此何為, 我已經三度相會, 畢竟不知到此何幹也。意其欲以 所學易吾周孔之學，則又太愚，恐非是爾). ${ }^{17}$ Li Zhi who swung between admiration for Ricci and incomprehension of his purpose used a tone different from that of Ricci. Ricci said that "he [Li Zhi] believed that the Christian law was the only true way of life." ${ }^{18}$ Ricci talked warmly of his debate with Sanhuai in his History of Expedition. ${ }^{19}$ I will now present two other personalities who earned their jinshi in I 589: Wang Kentang and Zhu Shilu.

Wang Kentang is one of first disseminators of Ricci's works, before Feng Yingjing 馮應京 (I 555-I606) and Li Zhizao 李之藻 (I 565-I630). Wang Kentang is the son of Wang Jiao 王樵 (I 5 I I-I 599), Vice-Minister of Justice in Nanjing. He is a jinshi of I 589 . Among his tongnian, we can mention Jiao Hong 焦泣, Feng Congwu 馮從吾 (I556-1627?), Gao Panlong 高攀龍 (1562-1626) and the famous painter and calligrapher Dong Qichang 董其昌 (1555-1636). The name of the latter appears also in the list of Lin Jinshui, but we cannot confirm that an encounter took place between Ricci and Dong Qichang, a close friend of Wang Kentang. Wang Kentang served successively as Assistant Compiler (shujishi 庶吉士) and Reviser (jiantao 檢討) at the Hanlin Academy, Vice-Director of the Messenger (Xingren si fu 行人司副) in Nanjing, Administration Vice-Commissioner (canzheng 參政) of Fujian Province. ${ }^{20}$ His works include the Lunyu yifu 論語義府 (Hidden Sense of the Analects), Shangshu yaozhi 尚 書要旨 (Outline of the Book of Documents), Lüli jianshi 律例箋釋 (Commentaries on Laws and Jurisprudences [of the Ming]). This last work is a development of the Du lï sijian 讀律私箋 (Personal Readings of Legal Texts), written by his father Wang Qiao, ${ }^{21}$ whom Ricci also met in Nan-

${ }^{17} \mathrm{Li}$ Zhi (20II), Xu Fenshu, juan I, p. 520. For the French translation of the letter of Li Zhi, see J. Gernet, Chine et christianisme. La première confrontation (Paris: Gallimard, I992), pp. 29-30.

${ }_{18}^{18}$ China in the Sixteenth Century: The Journals of Mattherw Ricci I583-1610, p. 334.

19 See for his dispute with Sanhuai, chapter 7 of the book 4 of Matteo Ricci, Lettere, pp. 3I 3-8.

${ }_{20}$ Mingshi, juan 221, p. 5818.

${ }^{21}$ For the legal aspect of Wang Kentang, see Chiu Peng-sheng (邱澎生), "Youzi yongshi huo fuzuo zisun: Wan Ming youguan falü zhishi de liangzhong jiazhiguan,” (有資用世或 福祚子孫: 晚明有關法律知識的兩種價值觀; Taking Law Seriously: Two Types of World Views about Legal Knowledge in Late Ming China) Qinghua xuebao (清華學報; Tsing Hua Journal of Chinese Studies), 33-I (2004), pp. I-43. 
jing. In Chinese history, Wang Kentang is remembered as a renowned physician. His Zhengzhi zhunsheng 證治準繩 (Standard of Diagnosis and Treatments) is still today considered a masterpiece of Chinese medicine. Wang Kentang was also a calligrapher and a collector of calligraphy. In I6IO, the year of Ricci's death, Wang Kentang compiled one of the most beautiful calligraphy collections of the Ming period: the Yugang zhai jitie 鬱岡齋集帖 (Calligraphic Reproduction by the Master of the Studio Yugang). His Yugang zhai bizhu 穮岡齊筆塵 (Writings by the Master of the Studio Yugang) in four juan presents itself as a compilation of his commentaries on the Classics, Buddhism, medicine and the Yijing 易 經 (Book of Changes). The book also presents miscellaneous informations from Western mathematics and astronomy, stemming in part from his exchanges with Ricci, whose Jiayou lun 交友論 (On friendship) and the Ershiwu yan 二十五言 (Twenty-five Paragraphs) are included. Ricci said that Wang Kentang had sent one of his disciples to learn mathematics from him: "This third pupil had been sent by his master, who was a distinguished philosopher of the faculty of the Royal College of Pekin, called Hanlin. This faculty is composed by the most brilliant of the highly educated of the realm, and it is considered to be a singular honor to be chosen for it." ${ }^{22}$ The Yugang zhai bizhu is mentioned in the Shijing bishu 詩經禆疏 (Exegetic Interpretation of the Book of Odes) of Wang Fuzhi 王夫之 (I619-1692) and the Wuli xiaoshi 物理小識 (Modest Opinions on the Principle of Things) of Fang Yizhi 方以智 (I6I I-I67I). Wang Kentang had studied Buddhism from the Master Zibo Zhenke 紫柏真可 (I 543I604) and wrote two commentaries on the School of Pure Mind (weishi 唯識, consciousness-only).

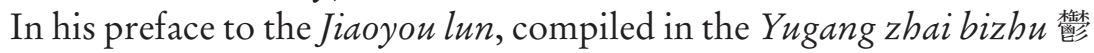
岡齋筆塵, Wang Kentang wrote:

Sire Li offered me the Jiaoyou lun in one juan. What flavour! Its words allow one to recover from illness. The book by far surpasses Mei Sheng's Qifa. Since he is not sufficiently familiar with Chinese, I deleted or embellished some parts of the text before the compilation.

利君遺余《交友論》一編, 有味哉! 其言之也, 病懷為之爽然, 勝枚生《七 發》遠矣。使其素熟于中土語言文字, 當不止是。乃稍刪潤, 著于編。23

${ }_{22}$ China in the Sixteenth Century: The Journals of Matthew Ricci I $583-1610$, p. 328.

${ }^{23}$ Wang Kentang, Yugang zhai bizhu (鬱岡齋筆塵), juan 3, coll. “Beijing tushuguan guji zhenben congkan” (北京圖書館古籍珍本叢刊), n ${ }^{\circ} 64, z i b u$ 子部 - zajia lei (雜家類) (Beijing: Shumu wenxian chubanshe 書目文獻出版社 (Reprinted of the Wanli Era's version 萬曆影印本), p. 548. For Mei Sheng, see the Hanshu, juan 51, pp. 2359-65. 
The Siku quanshu zongmu tiyao 四庫全書總目提要 (Annotated Catalogue of the Complete Imperial Library) describes the Jiaoyou lun in nearly the same words, showing that the book "was corrected by [Wang] Kentang” (為肯堂所點竄矣). ${ }^{24}$ All available documents confirm that the Jiaoyou lun was composed at the invitation of the Prince of Jian'an in Nanchang in I 595, as supposed by the author himself in the preface of the text. Wang Kentang is right to compare the Jiaoyou lun to the Qifa 七 發 (Seven Stimuli) of Mei Sheng 枚乘 (?--I40). First, the two texts, which emphasize a form of stoic ethics, are addressed to princes. Wang Kentang, a physician, did not forget the therapeutic virtues of the Jiaoyou lun, which manifested themselves both at a philosophical and at a linguistic level. We know that at the end of the Qifa, written by the Prince of Chu at the time of the Han Dynasty, after listening to a visitor quoting great philosophers (Confucius, Laozi, Zhuangzi, Mencius and Mozi), "[he] suddenly awoke to the speech of sages or disputers” (渙乎若一㯖聖人辯 士之言). “He could not help sweating, and was immediately cured” (涊然 汗出, 霍然病已). ${ }^{25}$ The therapeutic effects of the Jiaoyou lun mentioned by Wang Kentang did not contradict the fact that Shi Xing 石星, an important mandarin, left his son, who suffered psychologically from failing the keju examination, in the care of Ricci.

The Yugang zhai bizbu 㯺岡齊筆塵 includes a number of passages from Ricci’s Ershiwu yan 二十五言, although it refers to it by another name: Jinyan 近言:

Sire Li also offered me the Jinyan. It seems to be easy, but his intention is profound. I record some passages and preserve them as if graven on stone.

利君又貽余《近言》一編, 若淺近, 而旨深遠矣。亦錄數條, 置之座石。26

Some commentators assume that Wang Kentang gave another title to Ricci's Ershiwu yan. Nevertheless, "Jinyan" (Approaching words) was probably the first title used by Ricci in Nanjing for his book, an expression which is a translation and paraphrase of Epictetus's (55-135) Enchiridon

${ }^{24}$ Yong Rong 永瑢 et al., Siku quanshu zongmu (四庫全書總目; General Catalogue of the Siku quanshu), reprinted (Beijing: Zhonghua shuju, 1965), zibu 子部, Zajia lei cunmu 雜家類存目, 2, p. I080.

${ }^{2 s}$ It is said in the Jiaoyou lun (交友論): “Friendship is the wealth of the poor, the strength of the weak, the cure of the sick” (友也, 為貧之財, 為弱之力, 為病之葯焉), Zhu Wenzheng (朱維錚), Zouchu zhongshiji (走出中世紀; Coming out of the Middle Ages), new edition (Shanghai: Fudan daxue chubanshe, 2007), p. I I 3.

${ }^{26}$ Wang Kentang, op. cit., p. 550. 
(Manual). With the exception of the fourth paragraph which is probably Ricci's own work. Wang Kentang includes in his Yugang zhai bizhu fourteen paragraphs offered by Ricci. ${ }^{27}$ When his Beijing friend Feng Yingjing edited the book in 1604 , the title Ershiwn yan became definitive. ${ }^{28}$ Perhaps the book was not given a title in Nanjing, since Ricci could not complete the translation by then. ${ }^{29}$ The Yugang zhai bizhu also records Ricci's scientific endeavours in Nanjing. The titles of a number of chapters of his Journals explicitly point to Ricci's pride at successfully disseminating scientific knowledge to the Chinese literati in Nanjing and in Beijing.

\section{Zhu Shilu}

Zhu Shilu 祝世祿, zi Yanzhi 延之, hao Wugong 無功, especially facilitated Ricci's stay in Nanjing. "Cioselinus [Zhu Shilu] was acting for all of them. He was very highly esteemed by everyone and was celebrated as a moral philosopher. Moreover, he was so well known as a writer of Chinese characters, and as a penman, an art more highly regarded in China than in Europe, that only a few lines of his sample writing sold in Nankin for a high price, equivalent to Julian, one-tenth of a ducat." ${ }^{\circ}$ Ricci mentioned him more than once in his Journals, but Chinese documents mentioning him are few. When Ricci arrived at Nanjing, he showed a few times his gifts destined to the Emperor. But he stopped as the number of visitors grew too great. So Ricci entrusted Zhu Shilu with his valuables. Before his last trip to Beijing, Zhu Shilu prepared everything: his visa, boat rental....

A native of Dexing 德興, Jiangxi province, Zhu passed with success the jinshi examinations the same year Jiao Hong and Wang Kentang did. In short, they are tongnian of the examinations of I 589 , chaired by Xu Guo 許國 ( I 527-I 596) and Wang Honghui, both tongnian of I 565. One of Ray Huang's books is titled: 1587 , A year of No Significance. Now some histo-

${ }^{27}$ C.A. Spalatin, Matteo Ricci's use of Epictetus (Waegwan: Pontificiae Universitatis Gregorianae, 1975), p. I8, cited in Li Sher-shiueh (李颔學), Zhongwai wenxue guanxi lungao (中外文學關係論稿; Essays on the Relations between Chinese and Foreign Literatures) (Taipei: Lianjing, 2015), p. I 20, note 69.

${ }^{28}$ Feng Yingjing (馮應京) prefaced the Tiangzhu shiyi (天主實義; The True Meaning of the Lord of Heaven) and the Jiayou. We cannot conclude that Feng and Ricci met in Nanjing, as originally supposed by J. Gernet, "La politique de conversion de Matteo Ricci en Chine,” Archives des sciences sociales des religions, 36 (I973), pp. 7I-89..

${ }^{29}$ Li Sher-shiueh (李通學), Zhongwai wenxue guanxi lungao (中外文學關係論稿; Essays on the Relations between Chinese and Foreign Literatures) (Taipei: Lianjing, 20 I 5), pp. I20-22.

${ }^{30}$ China in the Sixteenth Century: The Journals of Matthew Ricci I583-I6IO, p. 323. 
rians give an importance to the year I 587 , marking according to them the beginning of the latter Ming period. Probably the year I 589 also has some significance in the history of the civil examinations. We can make a parallel to the keju examinations of I057, chaired by Ouyang Xiu 歐陽修 (I007I072). That year, Su Shi 蘇軾 (I037-I IOI), his younger brother Su Zhe 蘇 轍 (IO39-I I I 2), Zeng Gong 曾恐 (IOI9-IO83), three of the eight celebrated prose writers of the Tang and Song dynasties, became tongnian. ${ }^{3 \mathrm{I}}$ The list can be extended with Zeng Bu 曾布 (I036-I I07), the younger brother of Zeng Gong, Zhang Zai 張載 (I020-1077), Cheng Hao 程影 (I032-1085), well-known Neo-Confucians. The case of brothers-tongnian represented by Su Shi and Su Zhe, Zeng Gong and Zeng Bu will again manifest itself in I 589 . More than five centuries later, the brothers Ou Daxiang 区大相 (?-I6I4) and Ou Dalun 区大倫 ( ?-I628), natives of Guangdong province, passed with success the Jinshi examinations of 1589 . Ou Dalun wrote in I624 a biography of his mentor Wang Honghui.

Like Jiao Hong, Wang Jiao, the father of Wang Kentang, Zhu Shilu wrote a commentary on the Laozi 老子. When he was in Jiangxi province, he had attended the conferences given by Wang Yangming's Zhejiang disciples: Qian Dehong 錢德洪 (I496-I 574) and Wang Ji 王畿 (I498-I 583). Like Jiang Hong, Zhu Shilu was a disciple of the scholar-official Geng Dingxiang 耿定向 (I 524-I 597). Geng Dingxiang and his brother Geng Dingli 耿定理 (I 534-I 584) were close friends of Li Zhi. "Soon after Geng Dingli's death, Geng Dingxiang and Li Zhi increasingly quarrelled over Li's unorthodox behaviour, intellectual views, and Li's neglect of his family obligations." ${ }_{2}$ Their disputes lasted ten years from i 585 to I 595 , the year of their last encounter. But their strained relationship had no impact on the one between Geng Dingxiang and Jiao Hong. The Cunmu 存目 (Reserved Catalogue) of the Siku quanshu zongmu 四庫全書總目 mentions the Huanbi zhai shiji 環碧齋詩集 (Poetic Collection of the Master of the Studio Huanbi, 3 juan) , Zhi du 尺牘 (Epistolary Collection, 3 juan), Huanbi zhai xiaoyan 環碧齋 小言 (Small Talks of the Master of the Studio Huanbi, s juan). In the Qianqing tang shumu 千頃堂書目 (Catalogue of the Studio of Qianqing), Huang Yuji 黄虞稷 (I629-169I) included the Zhu Wugong ji 祝無功集 (Works of Zhu Shilu, 8 juan). Peng Yuanrui 彭元瑞 (173 I-1803), in his Tianlu linlang shumu 天祿琳瑯書目 (Catalogue of the Tianlu Linlang Library), which in-

${ }^{31}$ Five with Ouyang Xiu, the examiner, and Su Xun 蘇洵 (I009-1066), father of the Su brothers. The father failed the very same examinations. The three others are Han Yu 韓愈 (768-824), Liu Zongyuan 柳宗元 (773-819) and Wang Anshi 王安石 (I02 I-I086).

${ }^{32}$ P.C. Lee, Li Zhi, Confucianism and the Virtue of Desire (Albany: State University of New York Press, 20I2), p. 6. 
dicates that Zhu Shilu prefaced Jiao Hong's Yangzheng tujie 養正圖解 (A Diagrammatic Commentary to Cultivate Rightness). The Yangzheng tujie were illustrated moral lessons used by Jiao Hong to teach the Crown Prince. When Ricci met Zhu Shilu, he was Great Secretary (jishizhong 給事 中) at the Ministry of Rites in Nanjing. Once again, the Ministry of Rites in Nanjing, headed by Wang Honghui, was the main focus point of Ricci's network. Far from being surprising, it must be underlined that the Ministry of Rites also handled foreign affairs.

Huang Zongxi 黃宗羲 (1610-1695), in his famous Mingru xue'an 明儒 學案 (juan 35), recorded the following passage of the Huanbi zhai xiaoyan 環碧齋小言. But Huang gives another title: Zhuzi xiaoyan 祝子小言:

Wrong views are widespread: the heart-mind is in the body, which is only the heart-mind. In fact, the body is in the heart-mind as the heaven incorporates the earth. The body is the earth and the heart-mind, Heaven. The tide results in bubbles. The body is a bubble, and the heart-mind, the ocean. The heart-mind precedes the body. While the illusory body perishes, the veritable and marvellous heart-mind does not. Therefore, Confucius agreed that one could die content in the evening if in the morning he heard the Way; ${ }^{33}$ this is also why Zhuangzi argued that fire could spread even though faggots were already consumed. ${ }^{34}$

謬見流傳, 心在身中, 身中直一團心耳。原來身在心中, 天包地外。身, 地 也; 心, 天也。海起伏漚。身, 漚也; 心, 海也。未有此身, 先有此心。幻身滅 後, 妙明不滅。所以孔子許朝聞而夕可; 莊生標薪盡而火傳。35

Huang Zongxi shares Zhu Shilu's view on the relationship between heart-mind and body. For Huang, confirming that "the body is in the heart-mind"(shen zai xin zhong 身在心中) really "puts forward what Confucian scholars of previous periods never expressed" (shi fa xianru zhi weifa 實發先儒之未發). This conception of the relationship between heart-mind and body indisputably belongs to the tradition of Mencius for whom the heart-min (xin 心) is a major part of the body (dati 大體), to be contrasted with its small parts (xiaoti 小體). This is why the heartmind can embody any organ of a person. This is also the point of view of Wang Yangming whose influence on Zhu Shilu is obvious in the following passage:

33 “朝闻道, 夕可死矣.” Lunyu 論語 (Analects of Confucius), chapter “Li'ren”裡仁 (On the virtue of humanity).

34 "Though the grease burns out of the torch, the fire passes on, and no one knows where it ends” (指窮於為薪, 火傳也, 不知其盡也), translation of B. Watson, The Complete Works of Zhuangi (New York: Columbia University Press, 20I3), p. 2 I.

35 Zhuzi xiaoyan, in Huang Zongxi (黄宗羲), Mingru xue'an (明儒學案; Records of Ming Scholars) (Beijing: Zhongguo shudian, 1990), juan 35, pp. 407-8. 
Wang Xinjian's contribution consisted of his contribution to the destiny [of our dynasty] in public affairs and to a revolution in [Confucian] learning. ${ }^{36}$ The people's spiritual immersion into incoherent doctrines can be traced back to a long time. A man who has no power divine enough to separate Heaven and Earth, to be a great light, cannot turn the [the wheel of] dharma for our Way.

王新建在事業有佐命之功, 在學問有革命之功。蓋支離之說浸灌 入人心髓久矣。非有開天闢地大神力、大光明, 必不能為吾道轉此法 輪。37

“Incoherent doctrines” (zhili zhi shuo 支離之說) may be an allusion to Zhu Xi's 朱喜 (I I30-I 200) learning which was lost in detail to Wang Yangming's followers. But Zhu Shilu refers to a Buddhist terminology (dharma) for qualifying Wang Yangming's "revolution". On this connection, Huang Zongxi adds: "It is not proper for a Confucian. This discourse defiling Nature stems from Buddhist influence” (非儒者氣象, 乃釋氏作用, 見性之 說也)..$^{8}$ The editors of the Siku quanshu 四庫全書 also mentioned Zhu Shilu's debt to Wang Yangming and his disciple Wang Ji 王畿. Like most of the literati (Wang Honghui, Jiao Hong, Ye Xianggao....) whom Ricci met in China, Zhu Shilu rarely talks about his contacts with the Jesuit father in his works. We can probably explain this reticence of the Chinese scholars-officials by their wariness towards the political situation. They did not need the propaganda Ricci did for Rome and the Jesuits. Nevertheless, Zhu Shilu dedicated this poem to Ricci: “To Ricci” (Zeng Li Madou 贈利瑪竇):

Ten years of travels tell a lot about the distance between Heaven and Earth, Leaving the Western sea, you have passed through a hundred kingdoms.

The civilization of our sovereign is known in such distant lands,

His tributaries come from everywhere: continents, oceans...

Bearded, you have blond hair and blue eyes,

Your clocks equipped with a dial sound on bells.

Convinced neither by Confucius nor by Buddha,

Your heart remains day and night near the Lord of Heaven.

A studio and a bed are enough for you to reach the infinite, Your learning suggests these esoteric teachings.

${ }^{36}$ Count of Xinjian is a posthumous title of Wang Yangming.

37 Huang Zongxi (黄宗羲), Mingru xue'an (明儒學案; Records of Ming Scholars) (Beijing: Zhongguo shudian, 1990), p. 408.

${ }^{38}$ Ibid., p. 407. 
Where is the master of the Tao who is no longer in our land?

Laozi passed to the West long before the arrival of Bodhidharma.

Speaking Chinese, dressed like Chinese [scholars], your hair is already gray, Under the Han, you would be ranked among the nine categories of translators. In order to introduce the Foreigner to our Majesty,

I continue to give money to our high-ranking officials.

十年一龩地天長, 百國來從西海洋; 應是吾君文告遠, 梯航無處不來王。 于腮黃卷深瞳碧, 鈡巧自鳴分百刻; 宣尼牟尼了不聞, 書夜一心天迟尺。 一齋一榻入無窮, 別學偏於象緯工; 道在何之非我土, 老聑西去達磨東。 華言華服欲華顛，漢制都從九譯傳; 一自變夷歸聖軌，至今分給大官錢。39

The poem gives a detailed description of the appearance of Ricci, his abilities and his religious beliefs. At the same time, the author does not hide his own belief in the superiority of his own culture. The clocks (zhong 鍾) were among the gifts Ricci prepared for the Imperial Court. The last two verses imply that Zhu Shilu, had to bribe a number of high-ranking officials in order to facilitate Ricci's last trip from Nanjing to Beijing. The word gui 歸 (return) implicitly means “transform”(guibua 歸化) or convert. It is not impossible that the poet (Zhu Shilu) wishes the radical "sinicization" of Matteo Ricci, not only in terms of appearance, language, dress but also beliefs. This hypothesis is reinforced by the presence of the term bianyi 變夷 whose literary meaning is "[to] transform the foreigner". Therefore, if Ricci and his companions succeeded in converting a number of Confucians like Xu Guangqi, Li Zhizao, Feng Yingjing, a number of Chinese literati also tried to "confucianize" them in return. In this sense, to call Ricci “[a] Confucian from the Far West” (taixi rushi 泰西儒士) is accurate.

\section{Conclusion}

Though Ricci never mentioned Wang Yangming, he was welcomed by Wang Yangming's followers, especially those of the Taizhou School, known by its openness to other religions. The tongnian network linking Wang Honghui and Zhao Kehuai since i 565 , the one linking Jiao Hong, Wang Kentang and Zhu Shilu since I 589 , and the master-disciple relation-

39 “Zeng Li Madou” 贈利瑪寶, in Zhu Shilu (祝世祿), Huanbi zhai shi (環碧齊詩, coll. “Siku quanshu cunmu congshu” 四庫全書存目叢書), jubu (集部), n 94 (Jinan: Qi Lu chubanshe, 1997), p. 220. 
ship between Wang Honghui and Jiao Hong, Jiao Hong and Xu Guangqi, were really helpful if not essential to the accomplishment of Ricci's mission. All of them showed sympathy for Ricci or his mission. It should be noted that in I 582 , the year of Ricci's arrival in Macau, the Great Counsellor Zhang Juzheng 張居正 (I525-I582) died. He had ordered the closure of all academies linked to Wang Yangming's intuitionist thought and the imprisonment of He Xinyin 何心隱 (I I I7-I 579), an active member of the Taizhou School. After his death, the Emperor Wanli killed or exiled every member of the family of his former preceptor. Thus, the prohibition of the Taizhou School ended at the very moment Ricci arrived in China. The successors of Wang Yangming certainly did not identify themselves with Ricci's missionary enterprise, and even less with the replacement of Confucianism with Catholicism. However, as unorthodox Confucians, they displayed a relative tolerance toward Christianity. Therefore, Ricci was accepted by many followers of Wang Yangming. On the other hand, Ricci did everything he could to approach Ancient Confucianism and was critical of Zhu Xi's philosophy. In some way, the critique of Zhu Xi was a convergence point between Wang Yangming's followers and Ricci. Before he arrived in Nanjing, Ricci had contacts in Guangdong or in Nanchang with Guo Yingpin 郭應聘, a jinshi of 1546 , Wang Pan 王泮, a jinshi of 1574 , and Zhang Huang 彰潢. All of them were followers of Wang Yangming. These literati sometime drew on Chan Buddhism to comment Confucian texts or public conferences. Wang Honghui, Li Zhi, Jiao Hong, Zhu Shilu, Wang Kentang were all interested in the interaction of two or three teachings (Confucianism, Taoism and Buddhism), which is one of the focus of the Taizhou School. They all established a friendly relationship with one or more well-known monks such as Zibo Zhenke, Hanshan Deqing, Sanhuai with whom Ricci himself debated. These Buddhist masters were also in search of common features between Buddhism and other teachings. They patiently commented some non-Buddhist classical texts. The atmosphere was to a degree conducive to academic exchanges between followers of different currents of thought on the ways to reach sagehood. In short, Ricci's critique of Buddhism shocked some Chinese literati. The exchanges between Huang Hui, a jinshi of 1589 and a fervent Buddhist, and the Jesuit father, reflect the opposition to Ricci's critique of Buddhism. ${ }^{40}$ It is easy to conclude that before his arrival in Beijing, the scholars-officials Ricci met were mainly followers of Wang Yangming. In Nanjing, his

${ }^{4 \circ}$ R. Po-Chia Hsia, A Jesuit in the Forbidden City. Matteo Ricci, I552-1610 (Oxford: Oxford University Press, 2010), p. 225. 
network grew but his main intermediary remained Wang Honghui. The impact of the tongnian network and of master-disciple relationships is crucial to Ricci's stay in Nanning, even though every tongnian of I 589 did not support Ricci's mission. Such is the case of Huang Hui. The situation changed in 1602 after Li Zhi's suicide. First, as of I 604, the members of the Donglin faction became more influent at the imperial court. They were opposed to Buddhism and advocated frugality in politics. Ricci and his companions tried to adapt themselves to the changing situation. On the one hand, they continued to meet their friends promoted from Nanjing, on the other hand, they forged new alliances in Beijing. For example, they got the powerful support of Feng Qi 馮琦 (1558-?), Minister of Rites and enemy of the Taizhou School. This new attitude stemmed from the constraints of the politics in Beijing but also from Ricci's pragmatic, if not opportunistic, calculations. Nevertheless, it stems from Ricci's reticence toward the syncretic attitude towards the three teachings displayed by the Taizhou School. Ricci was probably sensible to the fact that a number of scholars worked conjointly towards a moral refoundation and the critique of Buddhism. However, the Donglin faction did not reject all the contents of Wang Yangming's philosophy. Its members kept close contacts with the Jiangyou School (Jiangxi), which emphasized peacefulness and moral practices. This explains the good relationship between Feng Qi and Zou Yuanbiao, two tongnian of I 577. But the vicissitudes of history will involve the scholars of the Donglin faction in the conflict against Wei Zhongxian 魏忠賢 (I 568-1627), leader of the eunuchs. This political but not ideological confrontation temporarily ended with the triumph of the eunuchs. This was a major sign of the weakening of the Ming dynasty, whose fall was inevitable. 